University of South Florida

DIGITAL COMMONS

Digital Commons @ University of

@ UNIVERSITY OF SOUTH FLORIDA

South Florida

School of Geosciences Faculty and Staff

Publications

School of Geosciences

$9-1998$

\title{
GPS Measurement of Surface Deformation Around Soufriere Hills Volcano, Montserrat from October 1995 to July 1996
}

\author{
Glen S. Mattioli \\ University of Puerto Rico \\ Timothy H. Dixon \\ University of Miami, thd@usf.edu \\ Frederic Farina \\ University of Miami \\ Ellen S. Howell \\ University of Puerto Rico \\ Pamela E. Jansma \\ University of Puerto Rico
}

See next page for additional authors

Follow this and additional works at: https://digitalcommons.usf.edu/geo_facpub

Part of the Earth Sciences Commons

\section{Scholar Commons Citation}

Mattioli, Glen S.; Dixon, Timothy H.; Farina, Frederic; Howell, Ellen S.; Jansma, Pamela E.; and Smith, Alan L., "GPS Measurement of Surface Deformation Around Soufriere Hills Volcano, Montserrat from October 1995 to July 1996" (1998). School of Geosciences Faculty and Staff Publications. 486.

https://digitalcommons.usf.edu/geo_facpub/486

This Article is brought to you for free and open access by the School of Geosciences at Digital Commons @ University of South Florida. It has been accepted for inclusion in School of Geosciences Faculty and Staff Publications by an authorized administrator of Digital Commons @ University of South Florida. For more information, please contact digitalcommons@usf.edu. 


\section{Authors}

Glen S. Mattioli, Timothy H. Dixon, Frederic Farina, Ellen S. Howell, Pamela E. Jansma, and Alan L. Smith 


\title{
GPS measurement of surface deformation around Soufriere Hills volcano, Montserrat from October 1995 to July 1996
}

\author{
Glen S. Mattioli ${ }^{1}$, Timothy H. Dixon ${ }^{2}$, Fredric Farina ${ }^{2}$, Ellen S. Howell ${ }^{1}$, Pamela E. Jansma ${ }^{1}$, \\ and Alan L. Smith ${ }^{1}$
}

\begin{abstract}
Global Positioning System geodesy was used to measure surface deformation on Soufriere Hills volcano, Montserrat from October 6, 1995 to July 1, 1997 during initial dome growth and gravitational collapse. Our data from this period show non-axially symmetric horizontal displacements, and decreasing subsidence as a function of radial distance from the former topographic high of the volcanic edifice. Forward modeling suggests that surface deformation is caused by a shallow vertical dike $(<3 \mathrm{~km})$, which expanded approximately $1 \mathrm{~m}$, coupled with a deflating Mogi source at about $6 \mathrm{~km}$ depth. These inferred source parameters are in good agreement with independent observations of regional dike widths and preeruption magma storage depth.
\end{abstract}

\section{Introduction}

The surface deformation field of active volcanoes can be used to investigate magmatic and hydrothermal systems, and has traditionally been sampled with tiltmeters, electronic distance measuring, and precision leveling [McKee et al., 1984; Dvorak and Berrino, 1991; McGuire et al., 1991; Tryggvason, 1994]. Many of these techniques have been used prior to and during the current eruptive episode on Montserrat [Young et al., in press; Jackson et al., in press], but each has operational constraints, which may limit effectiveness. Global Positioning System (GPS) geodesy data collection and analysis can be automated and human involvement in the field can be minimized facilitating deployment on active volcanoes. Many active or restless volcanoes, however, do not currently have continuous, telemetered GPS stations on their flanks. While deployment of CGPS systems is increasing worldwide, indeed several stations have been installed and now operate on Montserrat, valuable deformation data may still be obtained using semi-permanent arrays during the initial stages of a volcanic crisis. In addition, because GPS observations can be tied to an external reference frame, outside the active volcanic zone, satellite geodesy can provide unique constraints to unravel a complex surface deformation field.

The current eruptive episode of Soufriere Hills ( $\mathrm{SH}$ ) volcano, Montserrat began July 18, 1995, after a 300 yr hiatus [Smith et al., 1997; Roobol and Smith., in press]. We report here GPS data collected from October 7, 1995 to July 28, 1996 during the phreatic, phreato-magmatic, andesite dome growth, and initial gravitational collapse [Hooper et al., 1997] phases of the eruption. We focus on this period because it preceded the massive dome collapse of late July to early August 1996 as well as the explosive eruption of September 17, 1996 (Sparks et al., in press; Young et al., in press).

\footnotetext{
${ }_{1}^{1}$ Department of Geology, Unıversity of Puerto Rico, Mayagiez

2 Rosenstiel School of Marine and Atmosph. Sciences, University of Miam
}

\section{Copyright 1998 by the American Geophysical Union.}

Our data show significant short and long term variation. The short term variations (periods less than a few months) represent a combination of noise from various sources, and possibly quasi-periodic elastic deformation cycles due to preeruption pressure buildup followed by eruption and pressure release. The available data are inadequate to resolve and quantitatively model these short term cycles. Two continuous GPS sites were installed within $3 \mathrm{~km}$ of the active center on $\mathrm{SH}$ during July 1996 by the University of Puerto Rico, Mayagüez (UPRM). We anticipate that these data will improve our understanding of noise sources and short term deformation cycles. The longer term variations, however, can be modeled as a linear process. GPS data from October 1995 to July 1996 are consistent with a simple model representing a combination

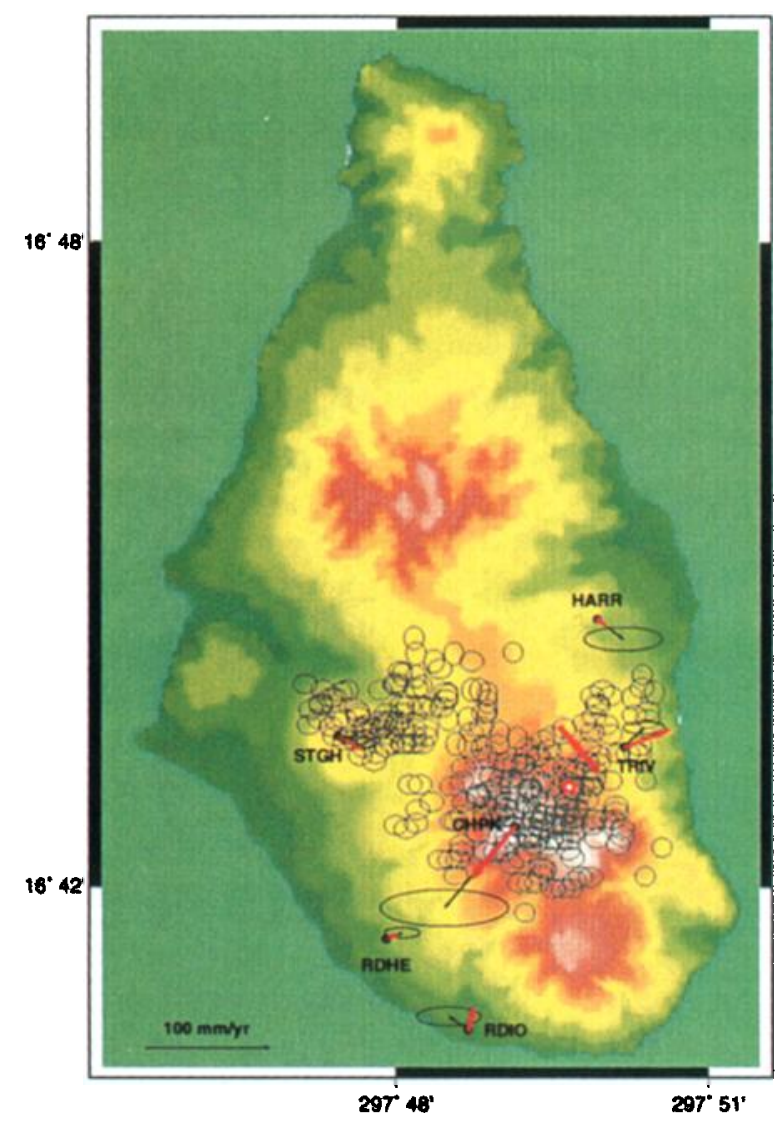

Figure 1. GPS site locations on $\mathrm{SH}$, horizontal velocities, and associated $95 \%$ error ellipses. Best-fit model velocities (red arrows), surface projection of point source (star) and dike (red line). DEM with horizontal postings of $25 \mathrm{~m}$ [Matias and Mattioli, unpub.]. Note that dike projection is not directly above Mogi source, and was adjusted to yield best-fit. Also shown is filtered seismicity from July 95 through July 96 (only A or B quality locations) for earthquake magnitudes greater than 0.5 [Miller et al., in press]. 
Table 1. GPS site velocities - October 1995 to July 1996

\begin{tabular}{lcrrr}
\hline Station & Days & North $^{\top}$ & East $^{\top}$ & Height $^{2}$ \\
\hline CHPK & 9 & $-65.1 \pm 6.0$ & $-56.4 \pm 20.8$ & $-78.5 \pm 31.6$ \\
HARR & 35 & $-16.0 \pm 3.9$ & $20.9 \pm 12.8$ & $-49.2 \pm 20.0$ \\
RDHE & 70 & $5.2 \pm 1.7$ & $12.8 \pm 5.7$ & $-55.0 \pm 9.4$ \\
RDIO & 31 & $10.7 \pm 3.1$ & $-15.4 \pm 10.3$ & $-32.3 \pm 16.6$ \\
STGH & 96 & $-3.5 \pm 1.4$ & $13.9 \pm 4.9$ & $-50.1 \pm 8.2$ \\
TRIV & 62 & $15.3 \pm 2.0$ & $16.1 \pm 6.9$ & $-51.4 \pm 11.4$ \\
\hline
\end{tabular}

Errors are $1 \sigma$ assuming linear fits to the dauly site posituon (all in $\mathrm{mm} / \mathrm{yr}$ )

1. Horizontal velocities are relative to CR01 on St. Croix, USVI

2 Vertical velocities are in ITRF-94

of evacuation of a shallow crustal magma chamber $(\sim 6 \mathrm{~km}$ depth), and horizontal displacement due to dike emplacement.

\section{GPS Data Collection and Analysis}

GPS data reported here were collected from six sites distributed around the SH volcano (Figure 1). Except for the site at Chance's Peak (CHPK), which prior to the current activity was the topographic high of the edifice, all sites were part of the Department of Ordnance Survey (DOS) triangulation network. The DOS network was last reoccupied and adjusted in 1974 [C. Calvert, written comm.], after the 1966-67 volcanoseismic crisis at SH [Shepherd et al., 1971]. Our GPS sites were selected based on ease of access, horizontal distance $(0.8$ to $3.6 \mathrm{~km}$ ) to the active vent, and their azimuthal distribution around SH. DOS monuments are small concrete cylindrical or rectangular plinths, which have a central $25 \mathrm{~cm}$ diameter steel pipe driven to refusal, $\sim 1-2 \mathrm{~m}$ below ground surface. Rigid plastic inserts (PVC), with clearly defined center marks, were shaped to obtain a tight fit, and then inserted into the pipes until refusal in order to make the DOS monuments suitable for a GPS antenna setup. The original DOS monument located at the summit was destroyed prior to the current volcanic activity. For the new CHPK monument, we chose a steel anchor bolt $(\sim 10 \mathrm{~cm}$ diameter $)$, driven to refusal, which was used previously to secure a guy wire for a large antenna. The bolt was scribed with a punch to provide a fixed central point.

The UPRM GPS observations can be divided into four phases: 1) network establishment with L1-carrier phase observations during August 1995; 2) daily L1/L2 observations between October 7, 1995 and December 29, 1995; 3) network densification and expansion with nearly daily L1/L2-carrier phase observations between May 14, 1996 and August 8, 1996 ; 4) installation of two continuous GPS sites in July 1996 and intermittent reoccupation of all network sites from September 1996 to June 1997. Initial GPS observations were made by UPRM in late August 1995 using two Trimble GeoExplorer 6-channel, L1 carrier phase receivers with internal antennas. Our objective was to evaluate whether strain larger than the uncertainty in the DOS triangulation network had occurred between the time of last adjustment in 1974 and August 1995. Site coordinates, transformed into the WGS-84 reference frame, were provided by the DOS; an estimated reasonable uncertainty is $\pm 9 \mathrm{~cm}$ for baselines of 3 to $8 \mathrm{~km}$ [C. Calvert, written comm.]. GPS Ll baseline repeatability during the August 1995 survey was $3-5 \mathrm{~cm}$. Within these error limits, no statistically significant $\left(\begin{array}{ll}1 & \sigma\end{array}\right)$ deformation had occurred on SH relative position baselines between 1974 and 1995 [Mattioli et al., 1996]. Of course, we cannot preclude the possibility that the entire edifice underwent a large scale deformation, the effect of which might be small in terms of relative baseline changes across $\mathrm{SH}$.

With these observations in mind, dual-frequency GPS observations began on October 7, 1995 using three 9-channel Trimble 4000SSE receivers and Trimble 4000SSE/SST L1/L2 antennas with flat ground planes. These data have sufficient precision as well as other characteristics to enable site velocities to be referenced to an external frame well outside the volcanically active zone. The three receivers were moved among the 6 sites, and data were collected using a $30 \mathrm{~s}$ sampling interval for between 16 to $24 \mathrm{hr}$ per UTC day. One site usually remained fixed, while the other receivers were reset at new locations. Accordingly, two principal triangles were occupied: STGH-RDHE-TRIV (an inner triangle closest to the dome) and STGH-RDIO-HARR (an outer triangle farther from the dome). Dual-frequency GPS observations were reinitiated May 14, 1996 using four 12-channel Trimble 4000SSI receivers initially with Trimble 4000SSE/SST antennas. Trimble Dorn Margolin choke-ring antennas were substituted for the 4000SSE/SST antennas after the first two weeks of observation in this phase and have been used exclusively for all our subsequent GPS observations on $\mathrm{SH}$.

GPS data are analyzed in two streams: an initial, moderate precision data stream for near real-time hazard assessment, and a subsequent, higher precision data stream for modeling volcanic source parameters. The first data stream was analyzed in the field by UPRM using Trimble software (GPSurvey) along with broadcast ephemerides, and yielded relative baseline changes, reported directly to the Montserrat Volcano Observatory (MVO), usually within one day of observation. A subsequent high precision data stream was analyzed at the University of Miami (UM) several weeks after observation. Baseline comparisons show that the two sets of results are consistent within error [Mattioli et al., 1996]. Here we report our second set of results, obtained with the GIPSY software developed at the Jet Propulsion Laboratory (JPL) using high precision satellite orbit and clock estimates distributed by JPL [Zumberge et al., 1997]. Processing details are described in Dixon et al. [1997]. We restrict our discussion to the six stations that have at least ten months of dual-frequency observations during the period of phreatic, phreato-magmatic, dome growth, and collapse (i.e. October 1995 to July 1996).

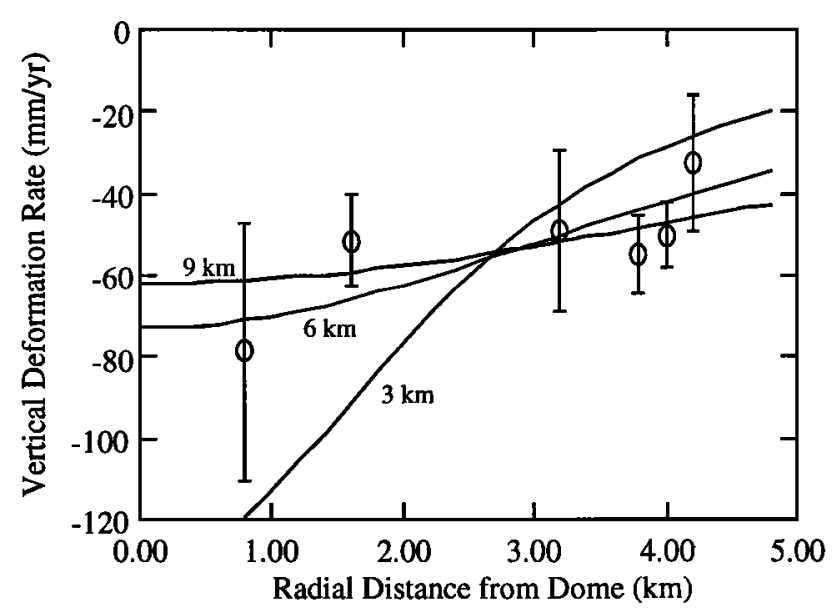

Figure 2. Mogi models and GPS vertical component velocities with $1 \sigma$ errors. $\Delta V$ was adjusted in each model for best-fit. Note observations only provide good constraints on minimum depth. 


\section{Results and Discussion}

Station velocities and errors $(1 \sigma)$ are shown in Table 1 , along with the number of observation days at each site. Station coordinates were computed in ITRF-94 [Boucher et al., 1996]. The vertical velocities in Table 1 are a linear weighted least squares fit to the daily position estimates in ITRF-94. For the horizontal velocities, a different procedure is required, since motion of the Caribbean plate relative to a global reference frame is poorly known [Dixon et al., in press]. We have therefore shown the horizontal velocities relative to a permanent IGS station (CR01) in St. Croix, $280 \mathrm{~km}$ to the northwest. This has the advantage of referring all our SH site velocities to a site outside the volcanically deforming zone as well as removing the majority of Caribbean plate motion.

The vertical velocities show a clear trend of decreasing subsidence away from the center of the edifice, consistent with decreasing volume or pressure of a simple Mogi source [Mogi, 1958; Figure 2], which we infer is analogous to a shallow crustal magma chamber. The horizontal velocities, however, are not consistent with this simple model. Seismicity in the initial stages of the eruption [Miller et al., in press] delineated two diffuse, linear zones of epicenters, oriented radially away from the lava dome near the center of the island and trending northwest and northeast (Figure 1). We interpret this to represent the effect of propagation and lateral growth of two sub-vertical dike swarms. During the period reported here, the northwest trend appears to be the more active, and the GPS data suggest that this is the dominant source of deformation. Of course, this interpretation may in part reflect the spatial aliasing inherent in any limited sampling of a complex deformation field [Walsh and Decker, 1971], but as we will show, our proposed model, although non-unique, is consistent with the GPS data and other independent observations.

We modeled our data assuming an elastic half space with two sources of deformation, with constraints as follows: 1. A deeper spherical magma chamber, implemented in the model using the Mogi point source approximation [Mogi, 1958], which is losing volume or pressure during the ongoing eruption as ash and gas are expelled from the volcano and andesitic lava is extruded to form the dome. Seismicity is abundant above $5 \mathrm{~km}$ [Miller et al., in press], but there is little activity below this depth, consistent with a mechanically

Table 2. Model Parameters and Results

\begin{tabular}{llll}
\hline Source & Parameter & Best Fit Model & Search Range \\
\hline Mogi & North & See Figure 1 & Fixed \\
& East & See Figure 1 & Fixed \\
& Depth & $6.5 \mathrm{~km}$ & $3-8 \mathrm{~km}$ \\
& Delta V & $-14 * 10^{\wedge} 6 \mathrm{~m} 3$ & $-(5-20) * 10^{\wedge} 6 \mathrm{~m} 3$ \\
& Radius & $0.5 \mathrm{~km}$ & Fixed \\
\hline Dike & North & See Figure 1 & $0-1 \mathrm{~km}$ \\
& East & See Figure 1 & $0-1 \mathrm{~km}$ \\
& Depth & $0.7 \mathrm{~km}$ (top) & $0.5-5 \mathrm{~km}$ \\
& Azimuth & $140^{\circ}$ & $130-150^{\circ}$ \\
& Length & $1.0 \mathrm{~km}$ & $1-4 \mathrm{~km}$ \\
& Height & $1.0 \mathrm{~km}$ & $1-2 \mathrm{~km}$ \\
& Angle & $90^{\circ}$ & Fixed \\
& Width & $1.1 \mathrm{~m}$ & $0.3-1.8 \mathrm{~m}$ \\
\hline
\end{tabular}

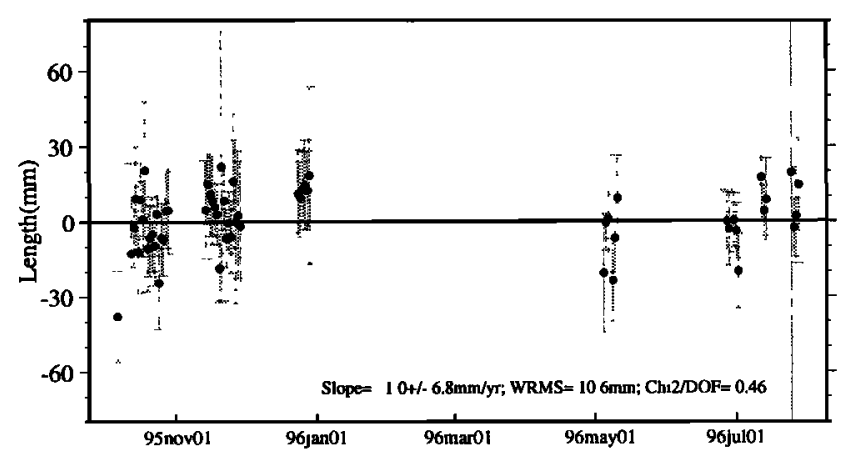

Figure 3. STGH-TRIV baseline time series from October 95 through July 96 . Note more rapid elongation than the linear fit during October 1995 to January 1996.

weak zone and high temperature and/or magma beneath $5 \mathrm{~km}$. We investigated a depth range of $3-12 \mathrm{~km}$ in our models. We fixed the horizontal location of the point source beneath the approximate geocenter of the dome, $\sim 750 \mathrm{~m}$ to the NE of CHPK, the former topographic high of $\mathrm{SH}$ prior to dome growth. 2. A dike trending northwest-southeast. Dike dip was fixed as vertical, with the surface projection of its along strike center constrained to be within $1 \mathrm{~km}$ of the surface projection of the center of the Mogi source. Along strike length was varied between 1 to $2 \mathrm{~km}$ toward the NW and SE, consistent with observed seismicity. We varied dike orientation $\pm 20^{\circ}$ around the epicentral trend of July 1995 to July 1996, and investigated values of cumulative dike growth perpendicular to the plane of the dike from 30 to $180 \mathrm{~cm}$ in $10 \mathrm{~cm}$ increments. Surface deformation due to the dike is modeled with the boundary element program 3D-DEF [Gomberg and Ellis, 1994]. Mogi source and dike source deformation were added to obtain the final deformation field.

We used a least-squares algorithm to obtain optimum model parameters; search ranges are listed in Table 2, and the best-fit surface projection of the dike and point source are shown in Figure 1. Predicted and observed horizontal velocities, along with their 95\% error ellipses also are shown in Figure 1. Our best-fit solution was obtained by adjusting only 9 parameters to fit a total of 18 independent geodetic observations (three velocity components at six sites). The best estimate of source depth is constrained geodetically to be $6.5 \mathrm{~km}$, in good agreement with phase equilibrium determinations for the source region of the hornblende-phyric andesite lava of the 1995 - $1996 \mathrm{SH}$ dome [Barclay et al., in press]. We also have calculated the effect of varying pressure or volume loss versus depth, the effect of visco-elastic rheology, and the contribution of variable material constants on the surface deformation [Howell and Mattioli, 1996]. These models give similar results to those reported here. We note that our best estimates of parameters, such as source depth, dike width, and dike azimuth are well within independent estimates and observations reported for other Lesser Antillean arc volcanoes [Wadge, 1986]. Although we have assumed a simple model of constant rate of deformation and volume change, the GPS data suggest that the surface deformation may be variable in time. In Figure 3, we plot a time series of baseline length from STGH to TRIV from October 95 through July 96 . While the data are reasonably well fit by a simple linear model, more rapid elongation during the period of initial dome growth (October 95 through January 96) is evident, and we infer that the edifice did undergo more rapid initial deformation as a result of the 
migration of magma into the shallow crust from $\sim 6 \mathrm{~km}$ depth. A more complex model is not justified at this time, given the errors and spatial distribution of the GPS data.

The surface deformation field is best-fit with a $\Delta \mathrm{V}$ of $-14 \mathrm{x}$ $10^{6} \mathrm{~m}^{3}$ from the Mogi source and transfer of $\sim 10 \%$ of this volume into the upper crust resulting in dike growth. The calculated $\Delta \mathrm{V}$ is approximately $1 / 2$ the observed cumulative volume of the dome up to late July 1996 [Sparks et al., in press]. This apparent difference may reflect the addition of magma to the chamber at $6 \mathrm{~km}$ from a deeper source over the observation period. This inference is significant because the volume of magma released in a previous deflation exerts control on the duration and volume of inflation required to reach a critical pressure threshold prior to the next eruption [Ewert et al., 1992].

Several features of our GPS observations and deformation model are consistent with regional trends. First, Lesser Antillean dike orientations show a bimodal distribution of azimuths to the NE and NW [Wadge, 1986]. Second, previously identified sector collapse features also show a regional pattern, with opening or failure directions having a bimodal distribution to the SW and NW [Roobol et al., 1983; Mattioli et al., 1995]. English Crater of SH, which opens to the NE, also has been interpreted as a sector collapse scar [Smith et al., 1997]. Both regional trends indicate that NE and NW trending extension may be common features of the active Lesser Antillean arc. We note that NE-SW extension is the dominant feature of our GPS observations from October 95 to July 96. Perhaps dike injection is kinematically and dynamically related to edifice failure in the Lesser Antilles. Similar models have been proposed for other composite [Guest et al., 1984; McGuire et al., 1991] as well as shield [Rubin, 1990; Moore et al., 1994; Owens et al., 1995] volcanoes.

Acknowledgments. We thank B. Baker, O. Butler, B. Darroux, M. Davies, J Dixon, D. Hooper, L Luke, J. Morris, J. Schellekens, G Skerrit, and S. Young for assistance in the field Helicopter support and expert piloting by A. Grouche and J. McMahon also are gratefully acknowledged. Equipment and field engineering support was provided by UCAR/UNAVCO We thank C. Demets of the University of Wisconsin for loaning us the Trimble 4000 receivers used during the intial portion of this experiment Two anonymous reviewers are also thanked for their comments Fundıng was provided by NSF (HRD-9353549 and EAR-9527273, ALS, PI), NASA (NCCW-0088, GSM, PI), British ODA (GSM, PI), and the Unıversity of Puerto Rico

\section{References}

Barclay, J., M. Carroll, J. Devine, C Gardner, M Murphy, M. Rutherfórd, Experimental phase equilibria of the Soufrere Hills magma and their constraints on the pre-eruptive storage conditions, Geophys. Res. Lett., in press.

Boucher, C., Z. Altamimi, M. Feissel, P Sillard, Results and analysis of the ITRF94, IERS Technical Note 20, 191 p., 1996.

Dixon, T. H, A Mao, M. Bursik, M Heflin, J Langbenn, R. Stein, F. Webb, Continuous monitoring of surface deformation at Long Valley Caldera with GPS, $J$ Geophys. Res., v. 102, 12,017-12,034, 1997

Dixon, T. H., F. Farina, C. Demets, P. Jansma, P. Mann, E Calais, Relative motion of the Caribbean and North American plates from a decade of GPS observations, J. Geophys. Res, in press.

Dvorak, J. J. and G. Berrino, Recent ground movement and seismic activity in Campi Flegrei, southern Italy: episodic growth of a resurgent dome, Jour. Geophys. Res, v. 96, p. 2,309-2323, 1991.

Ewert, J. D., in Monitoring Volcanoes: Techniques and Strategies Used by the Staff of the Cascades Volcano Observatory, 1980-90. Ewert and Swanson, eds., USGS Bull. 1966, 151-158, 1992.

Gomberg, J. and M Ellis, Topography and tectonics of the central New Madrid seismic zone: results of numerical experiments using a three dimensional boundary element program, J. Geophys. Res., v. 99, 20,299-20,310, 1994
Guest, J.E, Chester, D.K, and Duncan, A M., The Valle del Bove, Mount Etna: its origin and relation to the stratigraphy and structure of the volcano. Jour. Volcanol. Geotherm. Res., v. 21, p. I-23, 1984.

Hooper, D M, Mattioli, G S, and T. P Kover, Kinematic flow modeling and computer simulation for volcanic hazard assessment at Soufriere Hills volcano, Montserrat, B.W.I, in NASA University Research Centers Technical Advances on Educatton, Aeronautcs, Space, Earth, and Envtronment, eds. Jamshıdi, M et al., v. 1, 343-348, 1997.

Howell, E. S. and G. S. Mattiol, Modelling surface deformation measured at Soufriere Hills, Montserrat, 2nd annual Caribbean Conference on Natural Hazards, Kingston, Jamaica, Ed. R. Ahmad, v. 1., p. 32, 1996

Jackson, P., R. Robertson, G. Skerrit, J. Shepherd, and S. Young, Ground deformation studies I: EDM, Geophys. Res. Lett., in press

Mattioli, G. S., Jansma, P E., Jaramillo, L., and A L Smith, Sector collapse and the geomorphology of tropical arc volcanoes: a digital topographic investigation of Qualibou depression, St. Lucia, Lesser Antılles, Caribbean Journal of Science, 31, 1-11, 1995.

Mattioli, G S., Baker, B., Dixon, T., Farina, F., Hooper, D., Howell, E., Jansma, P , Smith, A.L., Young, S., GPS measurements of surface deformation during unitial dome growth at Soufriere Hills, Montserrat, BWI (abstract), EOS Trans. Am. Geophys. Union, 77, S291, 1996.

McKee, C. O , P. L. Lowenstein, P. de Saint Ours, B. Talai, I. Ititkara, and J. J. Mon, Seismic and ground deformation crises at Rabaul caldera: prelude to an eruption?, Bull. Volcanol, v. 47, p. 397-411, 1984.

McGuire, W., J. Murray, A. Pullen, and S Saunderps, Ground deformation monitoring at Mt. Etna; Evidence for dyke emplacement and slope instability, Jour Geol. Soc. London, v. 148, p. 577-583, 1991

Miller, A., R Stewart, R White, W. Ambeh, L Lynch, and W. Aspinall, Seismicity associated with dome growth, Geophys. Res Lett, in press.

Mogi, K., Relations between the eruptions of various volcanoes and the deformations of the ground surfaces around them, Bull Earthquake Research Institute, 36, 99-134, 1958.

Moore, J.G., Normark, W.R., and Holcomb, R.T., Giant Hawailan landslides, Ann. Rev Earth Planet. Sct., v 22, p. 119-144, 1994.

Owens, S, P. Segall, J. Freymueller, A. Mılklıus, R. Denlinger, T. Arnadótır, M. Sako, and R. Bürgmann, Rapid deformation of the south flank of Kilauea volcano, Hawaii, Science, v. 267, 1328-1332, 1995.

Roobol, M.J., Wright, J.V., and A.L Smith, Calderas or Gravıty-slıde Structures in the Lesser Antilles Island Arc?, Jour. Volcanol Geotherm Res., v. 19, 121-134, 1983

Roobol, M.J., and A.L. Smith, Pyroclastic stratigraphy of the Soufriere Hills volcano, Montserrat - Implications for the present eruption, Geophys. Res Lett., in press.

Shepherd, J. B., J. F. Tomblın, and D A. Woo, Volcano-seismic crisis in Monserrat, West Indies, 1966-67, Bull. Volcanol., v. 35, 143-163, 1971.

Smith, A. L., M. J. Roobol, E. Quiñones, and G. S. Mattioli, Volcanic history of Soufriere Hills, Montserrat, IAVCEI General Assembly Abstracts, Puerto Vallarta, Mexico, p 109, 1997.

Sparks, S, R. Robertson, P. Cole, A Lejeune, W McGuıre, M. Murphy, S. Young. The explosive eruption of Soufriere Hills volcano, 17th September, 1996, Geophys. Res. Lett., in press.

Tryggvason, E., Observed ground deformation at Hekla, Iceland prior to and during the eruptions of 1970, 1980-1981, and 1991, Jour. Volcan. Geotherm. Res, v 61, p 281-291, 1994

Wadge, G., The dykes and structural setting of the volcanic front in the Lesser Antilles island arc, Bull. Volcanol, v. 48, 349-372, 1986.

Walsh, J. B., and R W Decker, Surface deformation associated with volcanism, J. Geophys. Res, v 76, 3291-3302, 1971

Young, S, R. Robertson, L. Lynch, A. Miller, W. Ambeh, W Aspinall, J. Shepherd, S. Sparks, Overview of the Soufriere Hills volcano and chronology of the 1995-1997 eruption, Geophvs. Res. Lett., in press.

Zumberge, J. F, M. Heflin, D Jefferson, M. Watkins, F Webb, Precise point positioning for efficient and robust analysis of GPS data, J. Geophys Res, v. 102, 5005-5017, 1997

T. H. Dixon and F. Farina, Rosenstiel School of Marine and Atmospheric Sciences, Unuversity of Miamı, Key Biscayne, FL 33149 (email: tim@corsica.rsmas.miami.edu; fred@corsica.rsmas.miami.edu)

E S Howell, P. E. Jansma, G. S. Mattroli, and A. L. Smith, Department of Geology, University of Puerto Rico, Mayaguez, PR 00681-9017 (email ehowell @qualibou.upr.cluedu; pam @qualibou.upr.cluedu; glen@qualibou.upr clu.edu; al_smith@rumac.upr.clu edu)

(Received November 5, 1997; accepted December 23, 1997 ) 